\title{
Epithelial/myoepithelial carcinoma of breast: A report of hitherto unreported case
}

\author{
Tadashi Terada* \\ Departments of Pathology, Shizuoka City Shimizu Hospital, Shizuoka, Japan
}

Received: February 28, 2016

Accepted: May 20, 2016

Online Published: June 6, 2016

DOI: $10.5430 /$ crcp.v3n $4 \mathrm{p} 15$

URL: http://dx.doi.org/10.5430/crcp.v3n4p15

\begin{abstract}
Herein reported is the first case of epithelial/myoepithelial carcinoma (EMC) of breast. An 83-year-old woman noticed a circa $1.0 \mathrm{~cm}$ tumor of left breast. Core needle biopsies were diagnosed as invasive ductal carcinoma. Mastectomy with axillary lymph node dissection was performed, and gross examination revealed a circa $1 \mathrm{~cm} \times 1 \mathrm{~cm}$ tumor. Microscopically, the tumor was composed of invasive malignant cells forming tubular or cords structures with a scirrhous collagenous stroma. The malignant cells were composed by the following two elements; one was malignant epithelial cells and the other was malignant myoepithelial cells with clear or vacuolated cytoplasm. Immunohistochemically, the myoepithelial element was positive for p63, CD10, cytokeratin (CK) 34BE12, and CK5/6, S100 protein and alpha-smooth muscle actin. Both elements were positive for CK7, p53, and Ki67 (labeling: 16\%), estrogen receptor, progesterone receptor. Both elements were negative for CK20 and HER2/neu. The sentinel and level 1 lymph node were negative for metastasis (0/6). The tumor was pT1pNOcM0 and the stage was stage 1 . The patient had booster hormone therapy and is now alive 14 months without recurrence after the operation.
\end{abstract}

Key Words: Breast, Epithelium, Myoepithelium, Epithelial/myoepithelial carcinoma, Histopathology

\section{INTRODUCTION}

Mammary glands are composed of ductal epithelium, lobular epithelium, myoepithelium, and stromal cells; many kinds of tumors arise from them. ${ }^{[1-4]}$ Epithelial/myoepithelial carcinoma (EMC) composed of malignant ductal epithelium and outer myoepithelium and showing an organoid pattern with clear separation between epithelial and myoepithelial elements is not listed in 2012 WHO blue book of tumor classification of breast, ${ }^{[1]}$ and has not been described in the English literature, to the author's best knowledge. The author reports the first case.

\section{CASE REPORT}

An 83-year-old woman noticed a circa $1.0 \mathrm{~cm}$ tumor of her left breast. Mammography also identified the tumor with relatively well demarcation; no spicules were noted. Blood laboratory data and other images including chest and abdominal X-ray showed no significant findings. Breast needle cytology showed atypical cells but was decided to be indeterminate. Core biopsies showed malignant epithelial cells with clear cytoplasm and vacuoles in a collagenous stroma, and they were diagnosed as invasive ductal carcinoma (scirrhous carcinoma) by the author. Retrospective inspection showed that the carcinoma in core biopsies are the same as that of mastectomy specimens; therefore the diagnosis of core biopsy was not correct. Mastectomy and axillary lymph node dissection, but not breast-preserving wide excision, was performed; this procedure is recommended for resectable small breast carcinoma in NCI guidelines, to the best of the author's knowledge. A gross examination revealed a circa

\footnotetext{
*Correspondence: Tadashi Terada, MD, PhD; Email: piyo0111jp@yahoo.co.jp; Address: Department of Pathology, Shizuoka City Shimizu Hospital, Miyakami 1231 Shimizu-Ku, Shizuoka 424-8636, Japan.
} 
$1 \mathrm{~cm} \times 1 \mathrm{~cm}$ solid, rigid tumor (see Figure 1). No reconstruction surgery of the breast was carried out. Mastectomy without re-construction was selected because of the old age of the patient.

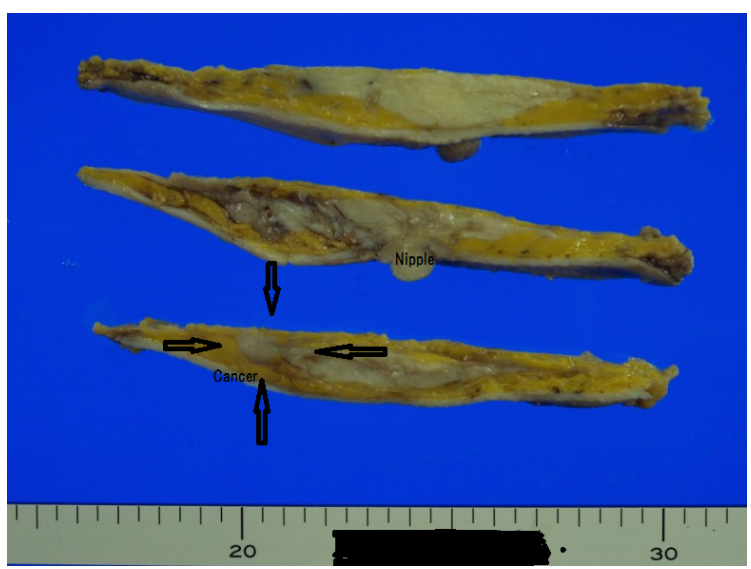

Figure 1. Gross features of the tumor (arrows)

It measures circa $1 \mathrm{~cm}$, and solid with relatively well demarcation
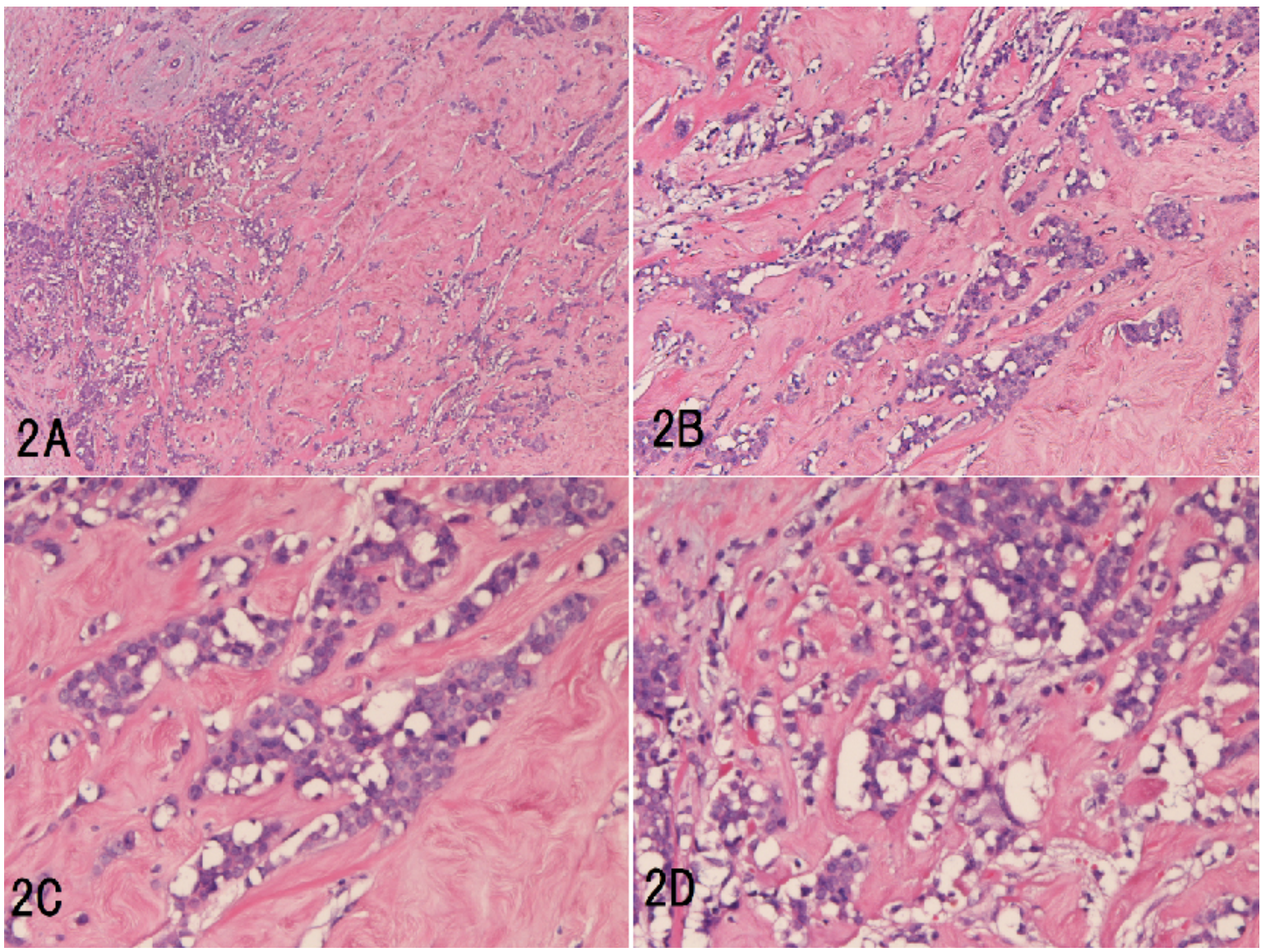

Figure 2. Histological and Immunohistochemical features of breast tumor

A: Low power view. The breast tumor shows invasive malignant epithelial cells with scirrhous pattern. The tumor cells form tubular and cord structures. HE, $\times 40$. B: The inner malignant epithelial and outer malignant myoepithelial natures are apparent. HE, $\times 80 . C$ : The malignant nature of the epithelial and myoepithelial (clear cytoplasm) cells are definitely seen. $H E, \times 200$. D: In some places, the malignant myoepithelial cells are aggregated, resembling to bubbles. $H E, \times 250$. 
An Immunohistochemical study was carried out with the use of Envision method. ${ }^{[5-7]}$ The malignant myoepithelial element was positive for p63 (see Figure 3A), CD10 (see Figure 3B), cytokeratin (CK) 34BE12 (see Figure 3C), CK5/6 (see Figure 3D), S100 protein, and alpha-smooth muscle actin (see Figure 3E). In contrast, the epithelial component was negative for these myoepithelium-related antigens. ${ }^{[3,4,8-10]}$ Both elements were positive for CK7, p53 (see Figure 3F), and Ki67 (labeling index: 16\%) (see Figure 3G), estrogen receptor (ER), and progesterone receptor (PgR). Both elements were negative for CK20 and HER2/neu. The pat- tern of companion diagnosis was $\mathrm{ER}=8, \mathrm{PgR}=6$, HER $=0$, and Ki67 labeling index $=16 \%$; therefore the Saint Gallen pattern ${ }^{[11]}$ was Luminal A, which is suitable for antiER therapy (Tamoxifen). The sentinel and level 1 lymph nodes were negative for metastasis $(0 / 6)$. The tumor was pT1pN0cM0 and the stage was stage 1 . The patient had booster hormone therapy (Tamoxifen: $20 \mathrm{mg} /$ day $\times 40$ $=800 \mathrm{mg}$ in total) because of positive ER and PgR, and is now alive without recurrence 14 months after the operation.

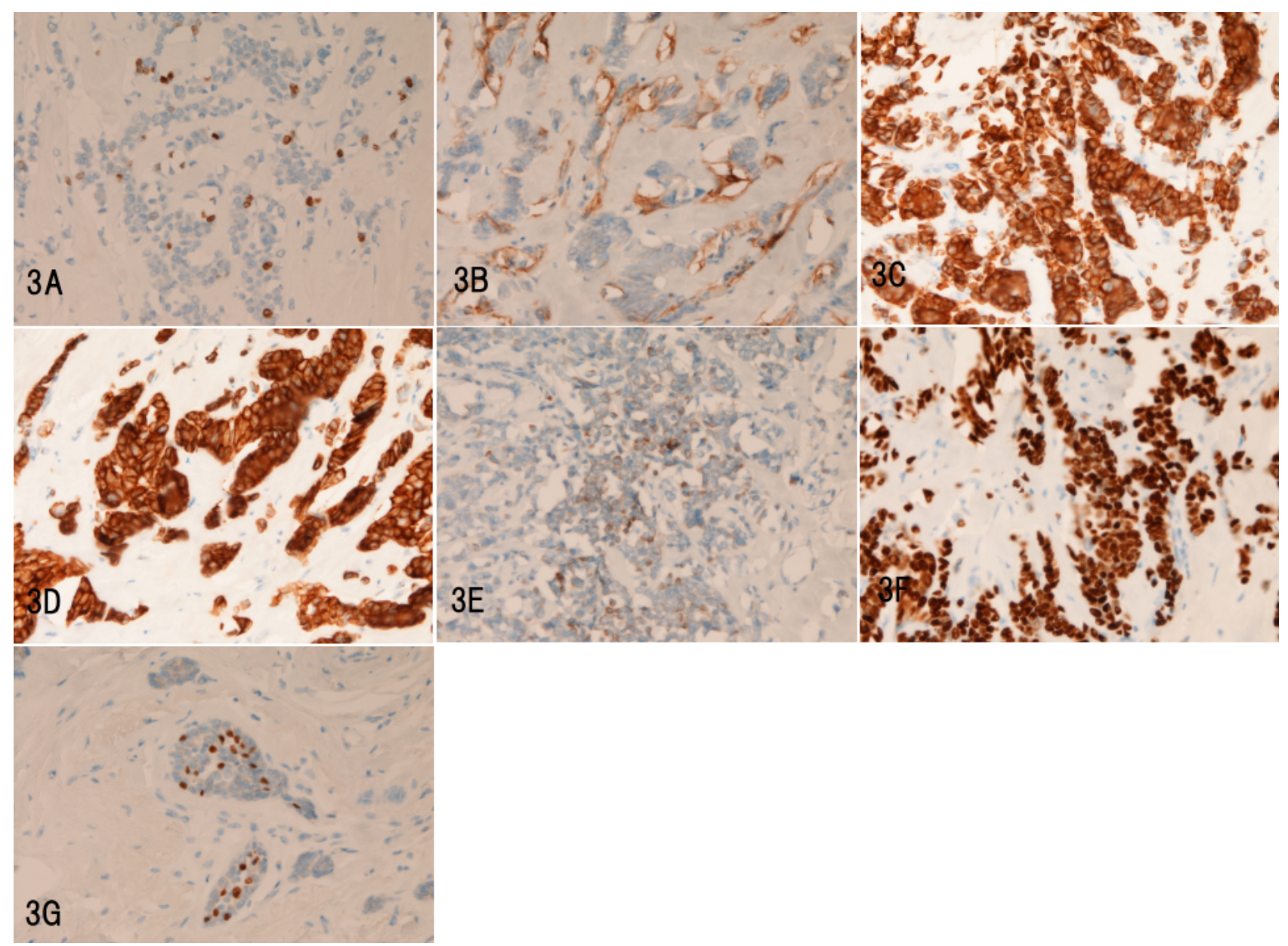

Figure 3. Immunohistochremically, the myoepithelial element is positive for p63 (A), CD10 (B), CK34BE12 (C), CK5/6 (D), alpha-smooth muscle antigen (E), p53 (diffuse) (F), and Ki67 (labeling index $=14 \%$ ) (G). A-G: $\times 200$.

\section{Discussion}

The pathological diagnosis of the tumor made by the author was EMC. No description of EMC is present in the updated WHO 2012 blue book of breast tumors, nor in the English literature. Therefore, the current tumor should be differentiated from mimics of EMC. It is obvious that the present tumor is made up of epithelial cells and myoepithelial cells. The inner location in the tumor glands of the epithelial cells Published by Sciedu Press and the negative myoepithelial markers (smooth muscle antigen, S100 protein, CK34BE12, CK5/6, CD10, and p63) in the epithelial cells suggest that the inner epithelial cells are ductal cells not myoepithelial cells. In general, the outer location in the tumor glands, clear cell changes, bubbly appearances, and nuclear hyperchromasia were histological features of myoepithelial cells; therefore the outer cells of the tumor glands of the current tumor are truly myoepithelial 
cells. In addition, they were positive for various myoepithelial antigens. Thus, the tumor is composed of epithelial and myoepithelial cells. Both the epithelial cells showed malignant features such as invasive growth, vascular permeation, nuclear hyperchromasia, increased N/C ratio, prominent nucleoli, high mitotic activity, increased Ki67 labeling index, and diffuse $\mathrm{p} 53$ expression. The most latter suggest p53 gene mutation. ${ }^{[12]}$ Thus, it is malignant tumor composed of epithelial and myoepithelial cells. It is most problematic to term this tumor. The author labeled this tumor as EMC. This is largely because the tumor consisted of malignant epithelial cells and malignant myoepithelial cells, whose separation is clear and organoid with inner epithelial cells and outer myoepithelial cells in tumor tubules and cords. If the two epithelial cells were much more mixed up, the author had termed it as malignant adeno-myoepithelioma ${ }^{[3]}$ or breast carcinoma with mixed ductal and myoepithelial differentiation or myoepithelial cell-rich carcinoma after Coiny et al. ${ }^{[13]}$ The present tumor is not adenoid cystic carcinoma because of the lack of cribriform pattern. ${ }^{[10]}$

In 2012 WHO blue book, the classification of breast tumors includes epithelial-myoepithelial tumors which in turn consists of adeno-myoepithelioma with carcinoma and adenoid cystic carcinoma (ACC) ${ }^{[14]}$ The former is benign adenomyoepithelioma with malignant carcinomatous focus, and the latter is composed of malignant epithelial cells and malignant myoepithelial cells both forming a characteristic cribriform pattern. The current tumor is composed entirely of carcinoma cells and lacked element of benign adenomyoepithelioma, thus being different from the former. The tumor did not present the cribriform pattern, thus being different from ACC.

In 2004, Coiny et al ${ }^{[13]}$ reported 6 cases of breast carcinoma with dual differentiation into epithelial cells and myoepithelial cells, and they termed these "breast carcinomas with mixed ductal and myoepithelial differentiation". The tumors were characterized by high nuclear grade (Bloom and Richardson grade 3), solid/nodular/sheet-like tumor cell arrangements, and rarity of duct formation. In their four cases, segregation between epithelial cells and myoepithelial cells are much more obscure than the current case. Immunohistochemically, all cases showed strong positivity for CK14, calponin, smooth actin, and muscle specific antigen. Epithelial membrane antigen and CK8 were positive in a similar proportion of cells. Of interest, foci of metaplastic carcinoma were seen in three cases (3/6: 50\%). Their term is not listed in the current 2012 WHO blue book. The preset case seems somewhat different from their 6 cases. ${ }^{[13]}$

The present case should be differentiated from metaplastic carcinoma. In 2012 WHO blue book of breast tumors, ${ }^{[15]}$ metaplastic carcinoma is defined as a group of neoplasms characterized by differentiations of the neoplastic epithelium into squamous cells and/or mesenchymal-looking elements including spindle, chondroid, osseous, and rhabdomyoid cells. In the current tumor, there were no areas of squamous differentiation and no areas of these mesenchymal differentiation; therefore the tumor is not metaplastic carcinoma of breast. Myoepithelial carcinoma is listed in one category of WHO 2012 blue book. ${ }^{[15]}$ It is a pure carcinoma composed only of malignant myoepithelial cells; therefore the current case is not myoepithelial carcinoma.

The clinical behaviors of carcinoma composed of epithelial and myoepithelial cells are obscure because of their rarity. Coyne et $\mathrm{a}^{[13]}$ reported the clinical course of 6 cases of breast carcinoma with dual differentiations into epithelial and myoepithelial cells. According to them, one patient died 23 months following diagnosis with metastatic carcinoma, another patient died of unrelated disease and four patients are alive with follow-up ranging from 18 months to 25 years. The biological behaviors of the neoplasms are not clear. Accumulation of much more cases are needed. In the present case, the tumor is small $(1 \mathrm{~cm}, \mathrm{pT} 1)$, no lymph node metastasis was seen ( $\mathrm{pN} 0$ ) and clinically no metastasis was found (cM0), thus being at stage 1 . Because no data of treatment of EMC were available, the patient was treated using conventional NCI recommended regimen, in this case partial mastectomy and dissection of sentinel and level 1 lymph nodes. After confirming negativity of cut margins, booster administration of Tamoxifen was added because the staining pattern was Saint Gallen Luminal A.

The myoepithelial cells are among interesting cell types which are distributed in mammary glands (a kind of apocrine glands), cutaneous sweat and apocrine glands, and salivary glands (major and minor). Prostatic gland has similar cells called basal cells. This kind of cell is located outside the glandular epithelium of above-mentioned glands and has both contractile and supportive functions. They contain actin filaments and other characteristic proteins such as p63, high-molecular weight CK including CK14, CK5, CK6 and CK33BE12, calponin, caldesmon, alpha-smooth muscle actin, S100 protein, and others. Thus, they are highlighted by immunohistochemistry for these antigens. These cells also can produce extracellular matrix proteins such as cartilage, bone, myxoid tissue, collagens, glycose-amino-glycan, proteoglycan and others, and can transform into specific cells producing these matrix proteins. This phenomenon is typically seen in pleomorphic adenoma (mixed tumor) of salivary glands in which cartilage and osseous tissue made by neoplastic myometrium are recognizable. In breast tumors 
also, cells of myoepithelial carcinoma and breast carcinoma with dual epithelial and myoepithelial differentiations can produce such extracellular matrix proteins. At present, the biology of myoepithelium is not extensively studied. Further studies remains to be done.

\section{CONFLicts OF INTEREST Disclosure}

The author declares no conflicts of interest.

\section{REFERENCES}

[1] Tan PH, Ellis IO. Myoepithelial and epithelial-myoepithelial, mesenchymal and fibroepithelial breast lesions: updates from the WHO Classification of Tumours of the Breast 2012. J Clin Pathol. 2013; 66: 465-70. PMid: 23533258. http://dx.doi.org/10.1136/jclin path-2012-201078

[2] Terada T. Clear cell variant of ductal carcinoma in situ of the breast. Breast J. 2012; 18: 279-80. PMid: 22530727. http://dx.doi .org /10.1111/j.1524-4741.2012.01237.x

[3] Terada T. Malignant myoepithelioma of the breast. Pathol Int. 2011; 61: 99-103. PMid: 21255187. http://dx.doi.org/10.1111/j $.1440-1827.2010 .02638 . x$

[4] Terada T. Ductal adenoma of the breast: immunohistochemistry of two cases. Pathol Int. 2008; 58: 801-5. PMid: 19067857. http: //dx.doi.org/10.1111/j.1440-1827.2008.02315.x

[5] Terada T, Kawaguchi M, Furukawa K, et al. Minute mixed ductalendocrine carcinoma of the pancreas with predominant intraductal growth. Pathol Int. 2002; 52: 740-6. PMid: 12685552. http: //dx.doi.org/10.1046/j.1440-1827.2002.01416.x

[6] Terada T, Taniguchi M. Intraductal oncocytic papillary neoplasm of the liver. Pathol Int. 2004; 54: 116-23. PMid: 14720143. http: //dx.doi.org/10.1111/j.1440-1827.2004.01594.x

[7] Terada T, Kawaguchi M. Primary clear cell adenocarcinoma of the peritoneum. Tohoku J Exp Med. 2005; 206: 271-5. PMid: 15942157. http://dx.doi.org/10.1620/tjem.206.271

[8] Terada T. Myoepithelial carcinoma of pharynx expressing KIT and PDGFRA. Int J Clin Exp Pathol. 2013; 6: 314-7. PMid: 23330018.

[9] Terada T. Primary cutaneous neuroendocrine tumor (atypical carcinoid) expressing KIT and PDGFRA with myoepithelial differentia- tion: a case report with immunohistochemical and molecular genetic studies. Int J Clin Exp Pathol. 2013; 6: 802-9. PMid: 23573331.

[10] Terada T. Pigmented adenoid cystic carcinoma of the ear skin arising from the epidermis: a case report with immunohistochemical studies. Int J Clin Exp Pathol. 2012; 5: 254-9. PMid: 22558481.

[11] Goldhirsch A, Ingle JN, Gelber RD, et al. Thresholds for therapies: highlights of the St Gallen International Expert Consensus on the primary therapy of early breast cancer 2009. Ann Oncol. 2009; 20: 1319-29. PMid: 19535820. http://dx.doi.org/10.1093/ann onc/mdp322

[12] Terada T, Shimizu K, Izumi R, et al. Methods in pathology. p53 expression in formalin-fixed, paraffin-embedded archival specimens of intrahepatic cholangiocarcinoma: retrieval of p53 antigenicity by microwave oven heating of tissue sections. Mod Pathol. 1994; 7 : 249-52. PMid: 8008749.

[13] Coyne JD, Dervan PA, Barr L. High-grade carcinomas of the breast showing patterns of mixed ductal and myoepithelial differentiation (including myoepithelial cell-rich carcinoma of the breast. Histopathology. 2004; 44: 580-4. PMid: 15186273. http: //dx.doi.org/10.1111/j.1365-2559.2004.01891.x

[14] Schmitt F, Tan PH, Dabbs D, et al. Myoepithelial and epithelialmyoepithelial lesions. In Lakhani SR, Ellis IO, Schnitt SJ, Tan PH, van de Vijver, M.J (Eds) WHO classification of Tumours of the Breast, Fourth Edition. IARC. Lyon: 2012. p120-3.

[15] Reis-Filho JS, Lakhani SR, Gobbi H, et al. Metaplastic carcinoma In Lakhani SR, Ellis IO, Schnitt SJ, Tan PH, van de Vijver, M.J (Eds) WHO classification of Tumours of the Breast, Fourth Edition. Lyon: IARC; 2012. p48-51. 